\title{
Regions as Networks: Towards a Conceptual Framework of Territorial Dynamics
}

\author{
Carlos Brito and Ricardo Correia
}

Additional information is available at the end of the chapter

http://dx.doi.org/10.5772/46093

\section{Introduction}

Regions are frequently indentified as mere containers of activity that are confined to static territorial borders. Such an approach does not provide an accurate image of the specificities of territorial dynamics and gives rise to political management options which are exceedingly focused within territorial limits. The cluster concept defined by Porter [1, 2] is a clear example of such regional characterisation. According to this author, clusters are groups that are geographically near associated companies and institutions linked by similarities and complementarities in a certain domain [2]. The cluster is a strong organisational model, according to Porter, which provides efficiency, effectiveness and flexibility [1]. Along this line of thought, the regional or cluster development depends upon the co-localisation of competing and complementary enterprises supported by a good infrastructure network and support services [3]. Such a concept focuses inside the territory and is based upon a list of material resources that should be made available to the region and the companies located therein.

Underlying the success formula is conglomeration of companies within a close geographical space. Clusters are thus highly typical realities [1] and invariably show some characteristics which will develop the region where they are located. However, these analyses do not include the entire multiple and compounding elements which, with their diversity, may help enhance development. There is not a single mechanism to explain how a dynamic region eventuates [4]. Martin and Sunley [5] indicate a lack of clarity in the conceptualisation as well as empiric insufficiencies in the advantages attributed to clusters, defining them as "one-model-fits-all". Nevertheless, many policies on regional development follow this direction. Stimulus packages are handed out to regions to promote their take-off, normally in the form of subsidies, infrastructures and tax deductions. Whilst these measures have a positive impact "they are certainly problematical when they occur in a vacuum" [6, 
p. 587], i.e., when they do not take into consideration the organisational and institutional basis of regional dynamism.

An institutional reference is clearly lacking in the explanation of spatial relationships in Porter's cluster concept [7]. Many regional developmental conditions are institutional and cultural, and are made up of "untraded forms of interdependency between economic agents, and hence they collectively constitute the relational assets of the regional economy (...) Relational assets of this sort are not freely reproducible from one place to another, and access to them is determined at least in part through network membership". This is often called the relational capital $[8,9]$ and is made up of social and economic relationships in a given geographical space [8]. The relational capital of a certain region is often one of its most important sources of success due to its inimitability characteristics [9].

Part of the advantages often attributed to clusters derives from the co-localisation of companies in a contiguous area and from the exchange of ideas and co-operation between them. A basic tenet for this approach shows more cooperation and interdependence between companies located near one another [10]. However, "the empirical evidence suggests that the prosperity and dynamics of clusters as compared to other locations may be unrelated to the co-location of firms from specific industries there, and that individual firms in clusters need not, on average, derive any unique advantages from their locations" [11, p. 450].

In a recent study on three winegrowing clusters located in Italy and in Chile, Giuliani [12] demonstrates that interaction and knowledge transfer in clusters surfaces in a selective manner for predetermined reasons and not randomly, whereas all can benefit and interact just by being there. When the cluster companies lack expertise and show low competences, the most advanced companies have no interest in linking with them and will cut off all internal interaction and connections in accordance with Coe and Bunnel [13, p. 439] when they state "innovation should not be considered in the context of an anarchic, placeless "space of flows" [14], but rather in terms of situated social relations between appropriate actors, in turn embedded in particular places".

Innovation and interaction cannot be explained by mere geographical proximity and company bundling $[15,16]$. "Neighbours might ignore or even hate one another. Local firms can be rivals and refuse any cooperation" [17, p. 48]. The relational component is essential to generate a distinctive element. Companies do not cooperate and interact just because someone orders them to do so. The success of a region does not arise of nowhere in an automatic process, but derives from decades of interaction between different companies and organisations located in various regions [4]. In the cluster concept, there is also a clear tendency to focus on the internal analysis and on local elements, which results in neglected external factors [18]. Conversely, "clusters can rarely be viewed as regional systems (...) because regions are strongly dependent on national institutions and other external influences" [7, p. 204]. Local initiative and its interdependence and dependence on other regions are the conditions a region needs to prosper [19]. This is due to actors who are "capable of acting in real time in different places, which means that their registers of actions 
go far beyond their mere location" [17, p. 53]. In this manner, what is most relevant for the analysis is not defining where an actor is located, but to determine in what ways their actions can evolve simultaneously in various geographical directions.

Clusters cannot be conceived solely with regard to their internal linkages. It is imperious to recognise their external dimensions $[4,20,21]$ since local economies reflect the policies and strategies of actors located in various regions [19]. The limitations associated to the traditional stand of economic geography and cluster theory have provided ground for a new trend within geography that reinforces the interactive and relational component. In fact "while regions (...) have been conceptualized intensively, less attention has been paid to their relations" [22, p. 540] and it is necessary to discover and research how interactions eventuate in different spaces [23]. This relational geography modifies the understanding of territorial dynamism and places the essence of regional economies within the dense interaction between all the various actors [24]. The industrial network approach is also characterising space relationally. The backdrop idea is that space and resources interact and affect each other [25]. The relevance of entrepreneurial interaction, irrespective of company localisation, is stressed in these approaches [4].

Due to their interactions, companies have become one of the most relevant actors in the shaping of territories. They create territorial characteristics in the way they train workers and in the way they introduce know-how into the region where they are implanted, and in their interacting they manage to bring about close contact between different territorial contexts [26, 27]. Although relationships and interactions established between companies and territories have become an important area of research "such relationships need clearer articulation and understanding." So far, "little attention has been paid to the precise nature of that relationship", and this has led to the fact that "the relationships between firms and territories are weakly conceptualized" [27, p. 346]. Equally neglected are the interactions between companies and other organisations creating economic value in the territory [28]. Indeed, classical systems of territorial management do not provide an accurate image of the mechanisms underlying relational and interactive dimensions of space, and thus the need to create knowledge in such a domain becomes obvious. Many territorial administrators "continue to maintain the reductionist assumption" and consider regions "as single, integrated, unitary, material objects to be addressed by planning instruments" [24, p. 624].

Because of (1) the obvious maladjustment between reality and the theories that assume regions as airtight entities, (2) and the theoretical insufficiencies in the explanation of the dynamic and interactive relationship between companies and regions, it is necessary to develop methodological tools that make it possible to approach space as a product of relationships and influences between various actors spreading far beyond their "artificial" physical boundaries. The objective of this chapter is to contribute to a better understanding of the dynamic and interactive relationship between companies and regions. Thus, we explore the contributions from relational geography concepts and the industrial network approach. We propose an analytical model that explains how companies' strategic action is reflected upon the territorial dynamics and structure and how such factors affect the companies' strategic action. 
This chapter is divided into six sections. Firstly, we address territorial studies from the perspective of the relational geography approach that challenges the traditional vision of territorial management and economic geography. The second section outlines in some detail the process of companies' interactions from the perspective of the Industrial Networks analysis. With this strong theoretical contribution, it is possible to understand companies' interaction and strategic action that constitute one of the most important factors for territorial dynamics, highlighted but not sufficiently explained by the relational geography. In the third and fourth sections, we proceed to apply the recent industrial network approach contributions to spatial analysis and in this way reinforce the research deriving from relational geography. In the fifth section, based on the aforementioned theoretical approaches, we develop a theoretical model aimed at answering what has been detected as lacking and that can constitute a base to reinforce knowledge in this area which remains relatively unclear. The final section presents our conclusions and also suggestions for further research.

\section{The relational geography contribution}

The concept of territory has been evolving due to the inclusion of relational elements in its characterisation, and this has originated what is currently known as "relational geography" [9, 27-34]. Relational geography represents "a theoretical orientation where actors and the dynamic processes of change and development engendered by their relations are central units of analysis" [31, p. 109]. It came about because the traditional approaches of economic geography were unable to explain micro dynamics which support different means of economic coordination [31]. In traditional approaches, regions are considered as economic actors, and the real actors (people, companies and institutions) with the capacity to change and mould the region are often ignored. The factors explaining the decision-making process for localisation are physical distance and cost reduction.

The relational approach is based upon the interactions occurring at a micro level because of diverse territorial processes. Space is analysed in a continuous relationship with the economy and in sharp contrast with previous positions that take it as a separate entity which is truly independent of economic actions [27, 30,33]. Thus, "economic actors and their action and interaction should be at the core of a theoretical framework of economic geography [30, p. 123-124] since the "economic action and interaction are the central object of knowledge in the analysis" [30, p. 125]. The conceptual basis for relational geography is based upon an institutional perspective [35, 36]. Here, actors' actions and objectives are not previously defined in order to conform to maximisation and rational logic. Instead, they are moulded by specific social contexts of the area where they are located at and which shape their actions. "We cannot understand economic geographies outside a set of formative, if perpetually changing and challenged, social relations" [37, p. 339].

There are three consequences of actions and economic interactions in the relational conceptualisation [28, 30]: (1) The relevance of the context - agents are considered to act within specific contexts of social, cultural and institutional relationships which create formal 
and informal relationships. On the other hand, theorists of relational geography try to frame the companies' actions within a specific space context and time framework [38]. (2) A pathdependence - a geographic place has "a memory which shapes the path of subsequent developments" [39, p. 603]. Past decisions influence future paths. (3) The contingency notwithstanding the importance of the past, economic processes are not predetermined, as the individual and collective strategies are contingent and may alter the existing structures. These characteristics imply that there are no general laws of economic action and so the generic policies of territorial development cannot be developed as an ever-successful recipe that works every time the ingredients are available (as is postulated in the cluster theory). Instead they must be based upon an evolutionary and contextual understanding of economic action [28].

The relational view of territory does not assume local, national or global spheres as different components from the organisation and from social action. Indeed, it promotes a relational understanding of each of those as a "nexus of multiple and asymmetric interdependencies among and between local and wider fields of action, organisation and influence [40, p. 153]. This point of view makes the network perspective an excellent way to approach the relational space. The main advantage of a network approach is that it can transcend all those scales without falling into the conceptual trap of preferring any one of those [32]. Geographical lenses can be used to focus on specific localised representations of the economic processes [30] taking into consideration that any scale is co-maker of a dynamic and complex geographic reality in its entirety [41].

The network approach makes it possible to pinpoint various interactions between actors located in various territories but whose results show up in specific places [32]. "Space is bound into networks and any assessment of spatial qualities is simultaneously an assessment of network relations" [42, p. 332] given that most of the dynamics of a territory may lie in actors localised in other geographical spaces [32, 33, 43]. Reinforcing this point, Malecki [44] states that some territories or places are capable of creating and attracting economic activities just because they are able to establish links with other spaces.

Progressively, regions become part of a global network forming connections and influences from multiple actors afar [29]. It thus becomes harder to distinguish between local and global relationships since there is a growing interdependence between them [43]. These networks can be more localised when they mainly depend upon local or global competences or when the major actors are physically distant [32]. According to Murdoch [42] we should concentrate on the links, chains, networks and associations and not simply on dualistic geographical visions between local and global. Locales are places of meeting and intersections of dynamic influences and not closed or restricted spaces [37]. This local meeting of diverse fluxes and interactions is responsible for its heterogeneity [45], and consequently no two regions are exactly the same.

Within the context of relational approaches, companies are noteworthy territorial actors [5, 30, 46-48] because decision-making at company level moulds the territory and its development process [12]. Consequently, to understand the development trajectory and 
territorial dynamics, we need to focus on companies and their interactions. During their activity, companies instil characteristics in the regions that welcome them and contact is established between resources from various origins. Simultaneously, their activity is influenced by territorial configurations. Acknowledging this role played by the entrepreneurial actors, relational geography proposes an approach between spatial and economic management. Space and economy are interlinked and cannot be analysed separately $[27,30,33]$.

The relationships between companies and the territory where they are located are obviously reciprocal [49]. Such reciprocal influence is well demonstrated in a paper by Schoenberger [48] "The Firm in the Region and the Region in the Firm". Such a relationship reflects the way in which companies' specific characteristics mingle with the specific characteristics of the territory. "While networks are embedded within territories, territories are, at the same time, embedded into networks" [32, p. 97], and that is the reason why such authors call companies "networks within networks". The dynamics and interactions associated with a region are referred to by the relational approach as essential for their development. "The tangible and intangible flows between the actors function as a blood circulation system in the region, enabling the system to meet the changing needs of the business environment" [50, p. 207]. The regions need their companies to have privileged links with internal or external actors capable of providing them with their dynamics. The external sources of knowledge are especially important to stimulate growth within that region [51].

A region must be linked to the outside world in what Owen-Smith and Powell [52] call pipelines to avoid declining due to entropy [53]. This concept is linked to knowledge originating in the outside world through a relationship between its diverse actors. However, when a region is linked to global production networks, such a fact does not automatically ensure a positive development since local actors may generate value in a manner that does not maximise the economic potential of that region. Local actors in a region may not be able to keep much of the value therein created [54].

Local companies must develop the capacity to assimilate the information and to efficiently apply it in order to create value. Cohen and Levinthal [55] use the term "absorptive capacity" to refer to the capacity of a company to identify, assimilate and exploit the knowledge deriving from its surroundings. To assimilate and benefit from new data, in a way that can create and develop new practices and activities, the companies must have the capacity to recognise, find and understand them. This acknowledgement demands the existence of previous knowledge. Territorial actors might not acknowledge this unless they have such previous knowledge. Accordingly, the benefit from this external knowledge depends upon local company actors' level of current knowledge, with the implication that any knowledge acquired in this manner is fully dependent on the existing knowledge base [56]. In larger companies, this knowledge derives from their research and development activities, but in smaller companies such knowledge is less formalised [57]. The capacity to absorb such knowledge in these smaller companies depends upon more tacit forms like learning by using and by doing, and it also depends upon their organisational configuration and the 
capacity to establish close relationships with various actors and the implementation of good practices in human resources [57-59].

Relational positioning emphasises the interdependent evolution between organisations and territories. However, it is crucial to possess a broader understanding of the processes which lie behind the interdependent actions that develop at a micro level [60]. There are many challenges to be faced in order to clarify the relationship between companies and the territorial dynamics. Namely, how to make theoretical connections between micro events at a company level and their spatial repercussions, normally only observable at a regional level [60]. The interactive relationship between companies and regions is not totally explained although the company is pinpointed as the key element in the relational space [30] since this approach does not entirely describe the company's organisation nor does it specify the basis for their interactions.

Authors of relational geography "are concerned with geographical space. Although they briefly refer to institutions, it is not made clear where (...) these fit in and how firms and institutions interact." [61, p. 5]. Existing publications reveal that research "has tended to have a naive view of the spatial character of firms and of the ways in which firms relate to territory" [27, p. 355]. Moreover, this gives birth to simplistic conceptions that are not in accordance with the interactive wealth of reality [27] and make it necessary to elaborate a broader analysis of the company and individual agents [31]. As far as the network approach is concerned, and notwithstanding numerous references and the relevance attributed to networks by the relational geography ideologues, seldom are such references made in an explicit manner [38,62,63]. "Much of the use of networks in economic geography has been rather selective, often metaphorical and little formalised" [49, p. 620]. The relevance of interlinking the local and outside worlds is stressed, but this process of connection and input of knowledge from outside is not described in its entirety.

Although there have been many current trends discussing the relational component of regions, there is not yet a robust conceptual corpus capable of making operational the conception of a socially constructed region based upon various dependencies. Indeed, one of the questions frequently asked and not yet properly answered, due to the limitations of relational geography, is: "how do firms interact with one another and what are the consequences for localised processes and structures?" [30, p. 138]. According to Waluszewski, "in order to investigate how companies co-evolve over time, including how local and non-local interaction contributes in this process, we have to use a tool that allows us to investigate the interactive features of industrial development" [4, p. 133].

The industrial network approach, a description of which follows, has, for the past thirty years, focused on the study of the interaction between companies. At the same time, it shows a notable adjustment with the characteristics conferred to the regions by relational geography and has made the interaction phenomena between companies and regions operational. 


\section{The IMP group perspective}

This approach to industrial networking began to develop as "a tool to investigate relationships that connected dyadic counterparts not only to each other, but also to a larger structure": the network [64, p. 30]. This is characterised by the interactions that evolve from relationships established between the different actors who have access to resources and undertake activities [74]. These three variables appear together (actors, resources and activities) in structures which have a distinctive trace in the way in which they interact. Such structures are called relationship networks. Lato sensu this concept is used to mean the grouping of all relationships which are developing in a given economic sector, and in a strict sense when it refers to those relationships belonging to a given actor [65]. One of the most important research objects in industrial network research is the long-term relationship, its origins, characteristics and effects [66]. A clear-cut rupture between the positions that defined borders between organisations and their environment is also a common characteristic of this approach. Due to the links formed by these relationships the organisations do not consider the environment as unchanging, but as an element with which they interact in specific ways according to the context [67-69]. As a result of the interdependence between the units under study [70], the behaviour of a company should be understood in the global context of their relations with others [71].

Due to the breadth of the network, the actors only have a limited cognitive capacity of the networks they belong to. They are restricted to a horizon, which limits the reality they know. When the interacting companies have differentiated network horizons, the visualisation of new opportunities for interaction is vastly improved [72]. To overtake such limited knowledge of the network, the companies create diverse cognitive structures depending on the interactions occurring within the network that result from the interpretation of past experiences [73] which have the capacity to shape their future actions. These network theories are described by Mattsson [74, p. 417] as "the actor's set of systematic beliefs about market structure, processes and performance and the effects of its own and others' strategic actions". They not only affect the strategic action of the actor which formulates them, but also that of others, as they can be transmitted to counterparts $[73,75]$. "Interaction with others is a major source and factor in the continuous adaptations in the cognitive structures guiding their behaviours" [76, p. 26].

Through these relationships actors exhibit to counterparts their theoretical formulations, and depending on their position have the capacity to influence them. Thus, changes in actor network theories, and consequently in the dynamism associated to the network, can occur, and result from the emergence of new relationships or from the interactions of already existing ones. Actors who interact with a company give it a position that depends on the set of relationships it has [73]. Any organisation occupies a position in the network. A company's network position is, however, a relative concept that is externally endorsed. Thus, there will not be two identical positions given by different actors to the same focal organisation [68]. 
A company's network position can be understood as a resource, an intangible asset that influences its action capacity and simultaneously, like any resource, supports and restricts its strategic action [77-79]. According to this perspective, Turnbull, Ford and Cunningham [78, p. 47] define position as "the company's relationships and the rights and obligations which go with them". Companies with a central position will have benefits resulting from the access to more information and opportunities in comparison to peripheral actors [80]. Network position also influences network theory as it is largely formed by the information resulting from relationships between actors [73]. The development of new relationships by the company changes the way its identity is perceptible in the network: i.e., its position. Due to relationships' dynamic character, a company's position is not definitive, and constantly changes with time $[76,81]$. As all the companies are connected and the positions are relative and conferred by each individual actor, the change of a company's position will affect the position of other companies [82]. Thus, positions may be positively or negatively connected, and the strength of one actor's position may, according to the situation, lead to the strengthening or weakening of the position of other companies [73]. However, the company can influence its position but this is a task that requires relationship management, the choice of preferred counterparts and the development of ties between resources [82].

The industrial network approach is sceptical about the direct control over resources a company can obtain since a substantial part of the resources available to the firm are under the direct control of other actors and can only be accessed by interactions and relationships in the network [83, 84]. Araújo, Dubois and Gadde [85, p. 498] state that "no company controls all the resources they require," and the competitive advantage of the companies is not only inside the borders of what it has and controls, but in all the interfaces it develops with others [86]. Resources are used together and in interaction with other resources and their characteristics are created through these combinations [64]. Nevertheless, in order to act, companies need to know how to interact, connect and make their resources grow. Access to external competences is not automatic as it requires a specific range of competences and relational efforts [87].

Companies do not prosper only because of their individual effort. They also depend on the relationships they have with others and on the nature of the direct and indirect relationships others have with them [79]. An organisation's results largely depend on how and with whom it interacts $[68,84]$. A company alone cannot build up its strategy $[68,83,88]$ since such a strategy derives from interactions and it is indexed to relationships. In this manner, the interactions and the relationships become as important, or even more important, as management, in order to influence the company's strategy [68]. It is crucial to invest in creating and strengthening relationships so that companies are able to strategically perform and adapt most of their competitive advantages to the surrounding environment [89]. In this way of thinking, strategy is defined by the way "in which a firm achieves exchange effectiveness in relation to other firms in the surrounding network that is how a firm initiates and reacts to changes in the network in such a way that the firm keeps on being valuable to the network" [90, p. 409]. The strategy is, thus, the result of a joint process in which many companies take part [91]. Consequently, most strategic activity revolves around influencing others and managing relationships within a context built upon interaction. 


\section{The territorial side of industrial networks}

The strength of conceptual research, by authors identified with the industrial network approach is currently so great that it surpasses the limits of industrial relationships that were at the centre of its origins. Indeed, valuable contributions to the understanding of the territorial dynamics appear from authors related with these approaches [4, 25, 26, 72, 92-96]. These approaches "instead of approaching place as a one-dimensional entity, as an object of analysis in itself, (...) allow us to investigate it as a multidimensional and embedded phenomenon interrelated with other variables" [94, p. 232]. The territory definition resulting from these studies is similar to those arising from the relational geography approaches: extremely dynamic, interactive and relational. Johnston and Araújo [95, p. 10] suggest that "territories are environments in which organisations are directly active and have a presence at a point in time, and are configured through relationships formed on the basis of activities and resources found within that specific environment". As a result of this vision, territory is no longer seen as, a simple container of economic activities is and is viewed rather as a structure of relations dependent upon specific resources.

Apart from attributing a dynamic character to regions, these authors also recognise the relevance of history for further development of any territory since they consider that regions should not be seen as individual entities merely linked with other geographical entities at a distance. Regions have different historical ancestries and dynamics which have diverse resource inflows and outflows that are capable of changing the spatial form and the relationships within the area [95]. This point of view is also shared by Waluszewski [4]. The author refers to territorial development as a process that is being built gradually and which does not happen overnight. More than looking into the current characteristics, it is essential to understand the historic patterns of the combination of resources available in the various regions.

Furthermore, Håkansson, Tunisini and Waluszewski [94] see space as a heterogeneous phenomenon; it is something simultaneously created and differently used by organisations with a significant dynamic component that changes with time. Accordingly, space is considered "as something that not only affects the individual company, but also the way the individual company interacts with other companies" because "the companies' interaction creates the place" [94, p. 231]. From the perspective of these authors, when territory is regarded as an organisation, each company inside it should be considered as a particular combination of resources that is part of a larger constellation. Thus, the characteristics of the social and institutional relationships that originate and develop in a territorial context are unique, inimitable, and affect the potential and attractiveness of the region where they are located.

Mota and Castro [96, p. 263] conceive industrial conglomerates as "territorially based networks" and state that "the dynamics in connections internal to those networks affect and are affected by local institutions as well as connections external to the territory". Territorial dynamics depend upon a network of connections resulting from the structure of relationships between companies 
since they are all involved in networks that outflow the regional boundaries. Hence, the dissemination of knowledge and network learning derives from a relational pattern and not only from physical proximity between actors [96]. Spatial proximity is just one factor that may be able to influence the relationships and network patterns. Other factors capable of influencing the relational pattern are social, technological and organisational proximity [97].

Baraldi [25] reinforces the interdependence between companies and territories previously recognised by relational geography by considering that "places are central to the life of every company, from the moment when it is born and throughout its various developmental stages". According to this author, this dependence is bidirectional: "companies interact constantly with various places, even without being fully conscious of doing so. Places affect companies' lives, but companies, alone or in interaction with others, also affect places" [25, p. 297]. Consequently, there are two levels (regional and industrial) in simultaneous and permanent interaction.

Regional interactions are based upon the interaction between the various actors belonging to those regions. Not all actors will become winners in the space interaction and some of them might even lose power, since such interaction exposes them to competition from other places and actors [26]. Multinationals are privileged actors in promoting the interaction of spaces and objects, and are defined by Baraldi, Hjalmar and Houltz [26] as place-connectors. In order to eventuate, interaction needs some form of relationship which becomes an important bridge to overcome spatial distances as well as cultural and competence distances [25]. These may overtake various places and create network configurations. In this manner, one space may be intimately dependent upon developments that are happening in another, and vice versa [92].

In short, the network approach proposes a vision that stresses the power of interaction and the gathering of resources in order to promote regional development. A company's horizon, position and interaction competences are more important than their mere localisation. The territorial dynamics are created according to the way in which companies value their resources, how they add/accumulate value and how they relate to each other (i.e., by what they do and how they do it) and not merely by existing. The potential for the interaction between space and companies' explanation revealed by the industrial network approach, is not yet sufficiently developed and focused on regions in a way that makes it possible to understand how such interaction occurs. Specifically, it is not explained how changes resulting from the company's strategic action reflect in the dynamics and territorial structure. Consequently, this gives rise to a research opportunity: to clarify the interaction between companies' action and territorial dynamics.

\section{Conceptual framework}

Literature about relational geography as well as about industrial network approaches question the generic and mechanical point of view that makes territorial development and the dynamics of replication one of the general factors of success. From the research 
conducted it is obvious that territories are entities each with their own history. As such they have their specificities, which make them heterogeneous and imply a continuous interaction with other organisations, namely, companies. This connection between companies and territories is a phenomenon which is both beguiling and complex and its study should be the central focus of research [27].

There are questions which are still unanswered relating to the influence and interaction between territories and companies and how they interact with, shape and mould each other [94]. Therefore, the central focus of the research model developed is to explain how companies' strategic action is reflected in the dynamics and territorial structure and how these territorial factors affect the companies' action. As a result of the theoretical approach followed, the answer to this question might be found not only in the company's dyadic relationships, but in the sum of its links enabling the company to belong to networks that are far beyond local scales. This implies that the model must be centred on three differentiated levels of analysis (Figure 1): the company, its relationship network and the territories where the company's network interacts.

The analytical model described in Figure 2 represents a structure which is both synoptic and integral showing the various levels of analysis being taken into consideration.

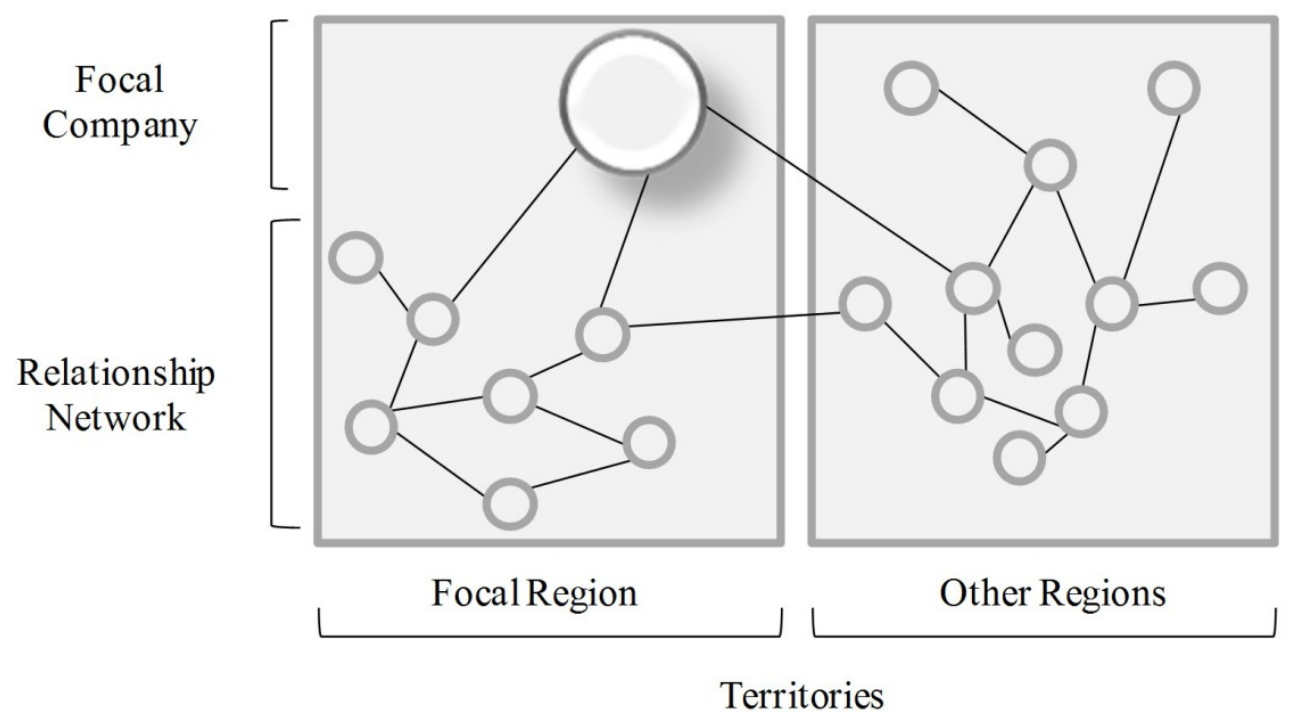

Figure 1. Levels of Analysis 


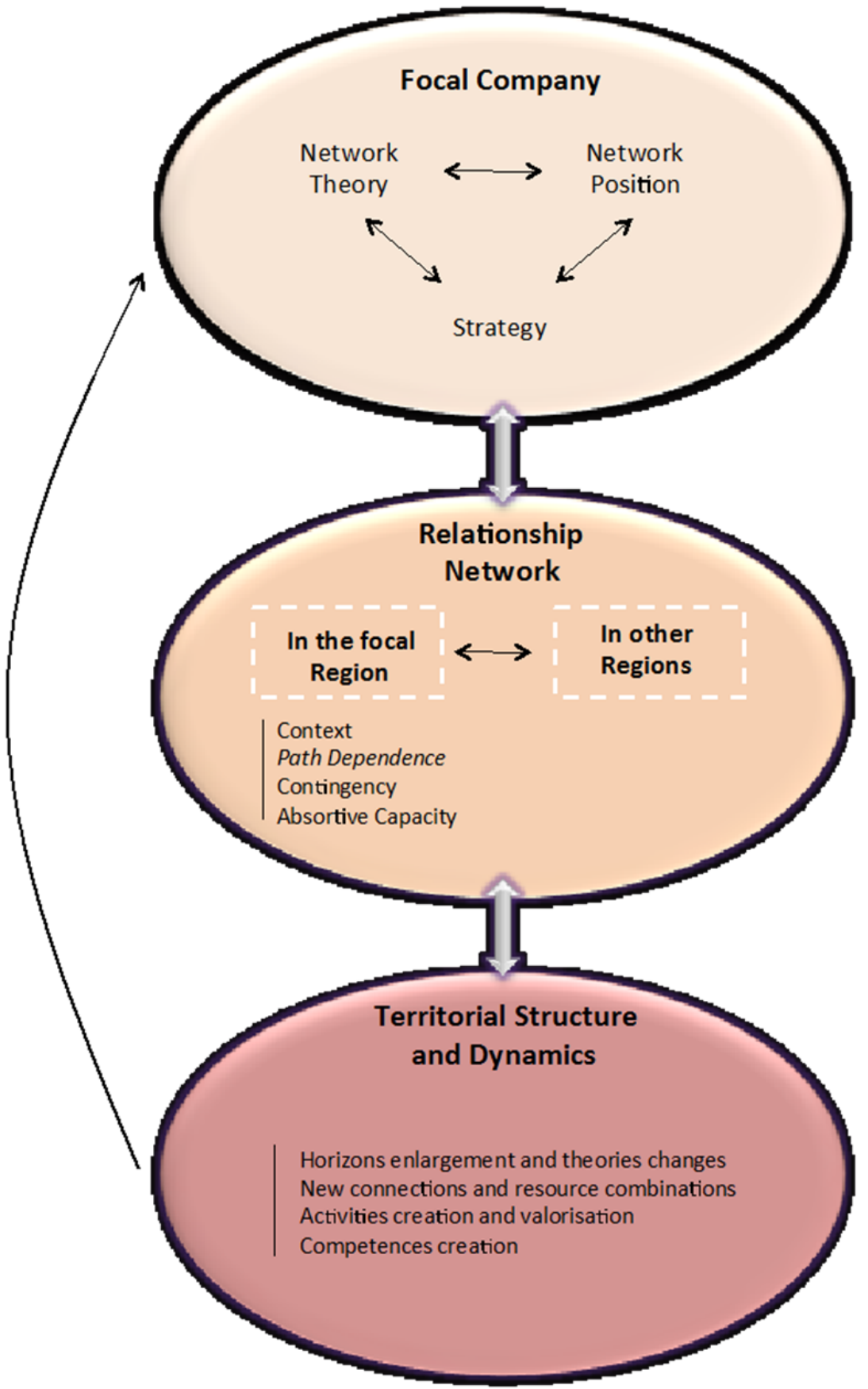

Figure 2. The Conceptual Framework 


\subsection{Companies}

Whilst the relevance of companies and the entrepreneurial relationships for territorial dynamics is obvious, the relational geography approach neither clarifies the mechanisms in which it originates nor does it describe its motivational processes. The companies, considered an instrumental territorial actor, are superficially characterised which is undeniably a major limitation. Equally notorious is the lack of knowledge about the reasoning behind the strategic action of the companies and the relevance of their relationship structure for their own development. This omission is even more serious since the relevance of the relationship structure for the interlinking between various regions is well known.

The interaction and network approach characterises in detail the entrepreneurial actors, their interaction processes and the reasoning for their strategic actions, and helps shed light on one of the most obscure areas of relational geography. Thanks to the interaction and network approach the companies lose their homogenous and anonymous characteristics, and acquire their own personality which accords them specific characteristics $[83,98]$. They are linked to the surrounding environment, depend upon it and influence it $[68,69]$.

Companies have a network theory, which guides their actions and the decoding of the behaviour of all actors surrounding them. They are positioned in the network of companies they are part of, according to their relevance and their relationship with counterparts. Access to resources from third parties, which are essential to add value to their internal resources and for the development of their activities, depends on the position they occupy. The theories and differentiated positions in the network lead the companies to specific strategic actions. Such strategic action undoubtedly influences the choice of counterparts they establish relationships with and the way in which such relationships occur.

\subsection{Relationship network}

With an approach based upon interaction and networks, we have been able to establish a great deal of knowledge on the concept of networks classified as vital in relational geography, but not sufficiently described. Networks are deconstructed into three major elements: actors, resources and activities [99, 100], and great relevance is given to the external component of each of those elements. The importance of the external analysis results from the connectivity of relationships. Relationships are connected since changes in any given relationship are likely to cause some kind of network effects [101, 102]. Any changes in the way the activities are coordinated and resources are used show up on a larger scale [64]. As a consequence, any change in a local network of relationships affects various other regions throughout the network. The same happens with the company's external links, which inevitably reflect upon the territory.

According to the company's strategic action, its relationships may be more localised or may spread outside the region. The pattern of a company's relationships with a region is also dependent upon the territorial characteristics. Here various factors have to be taken into 
consideration, such as the context, path dependence, contingency and the absorptive capacity that the territory reveals towards the company's actions.

\subsection{Territorial structure and dynamics}

Territorial dynamics are influenced by local connections and connections with external actors. Each organisation can be seen as a combination of resources from a constellation existing inside the territory [94]. This constellation is dynamic and can be influenced by interaction [103].

According to the focal network interaction with the region through the companies and installed organisations, various factors may occur which will have an impact on the territorial dynamics. These include horizons enlargement and a change of theories in the companies locally installed and, consequently, the awareness of new opportunities for interaction [72]. The development of new links between local companies can result in different combinations of resources. The creation of new activities, the valorisation of existing ones, and the creation of competences are also possible effects of the interaction between the company, its network and the region.

Changes in territorial structure and dynamics will impact on the focal company theory, and a readjustment of its strategy, which may affect its relationship network and, consequently, the whole of its relationship process with the territory.

\section{Conclusion}

Companies are fairly diverse. Even within the same economic sector their way of acting is different and this difference reflects upon the way their relationship network articulates in various regions. On the other hand, territories are also fairly heterogeneous and their particular development paths condition companies' activities. In this way, the relationship between companies and territories will always be specific and impossible to replicate. This specificity is not taken into account by the current literary trends which point to a generic thesis of development based upon the combination of various material factors inside a geographically delimited space.

The model based upon relational geography trends and the industrial network approach suggests that territorial dynamics are mostly dependent upon intangible factors and on interaction at various levels, and not on limited material components. From specific knowledge of a company based upon a particular relationship network, it is possible to focus on the interaction of this network with the characteristics of the territory. Some effects of this interaction result in changes to the territorial structure and dynamics.

Territorial configurations of company relationships may be more concentrated or dispersed in regional terms and create interaction in various spaces. It is not enough to have a substantial number of local links to create territorial dynamics. It is indeed essential that such links create competences that lead to the creation and rating of activities, which in turn 
originate new links and gather resources or contribute to a change in theories and a broader horizon for the interacting parts. Such effects largely depend upon the capacity of absorption by the territory. It is the interaction between the diverse organisational networks of the companies installed in a territory and the territorial characteristics that may create obstacles or advance the said effects.

The essential question challenging territorial administration is not subject to physical boundaries since all relationship networks may be connected to diverse spaces. In this manner, territorial managers must enhance the companies' internal links as well as develop the links to external networks where they will acquire dynamic factors. In order to do so, they must create a great deal of knowledge about companies' needs and strategies. This knowledge will allow the identification of companies which may be attractive and strategically compatible with organisational networks already established in the territory. The knowledge of entrepreneurial actors will enable territorial administrators to make efforts to reduce the relational distance.

\section{Author details}

Carlos Brito

University of Porto - School of Economics, Rua Roberto Frias, Porto, Portugal

Ricardo Correia

Polytechnic Institute of Bragança, Mirandela, Portugal

\section{References}

[1] Porter M. Clusters and the New Economics of Competition. Harvard Business Review. 1998;76(6):77-99.

[2] Porter M. Locations, clusters, and company strategy. In: Clark G, Feldman M, Gertler M, editors. The Oxford Handbook of Economic Geography. Oxford: Oxford University Press; 2000. p. 253-74.

[3] Porter M. On Competition. Boston: Harvard Business School; 1998.

[4] Waluszewski A. A competing or co-operating cluster or seven decades of combinatory resources? What's behind a prospering biotech valley? Scandinavian Journal of Management. 2004;20:125-50.

[5] Martin R, Sunley P. Deconstructing clusters: chaotic concept or policy panacea? Journal of Economic Geography. 2003;3:5-35.

[6] Scott A, Storper M. Regions, Globalization, Development. Regional Studies. 2003 August/October;37:579-93.

[7] Bathelt H. Geographies of production: growth regimes in spatial perspective (II) knowledge creation and growth in clusters. Progress in Human Geography. 2005;29(2):204-16.

[8] Camagni R. On the concept of territorial competitiveness: sound or misleading? Urban Studies. 2002;39:2395-411. 
[9] Storper M. Regional Economies as Relational Assets. In: Lee R, Wills J, editors. Geographies of Economics. London, New York, Sydney: Arnold; 1997. p. 248-58.

[10] Porter M. The Competitive Advantage of Nations. London: Macmillan; 1990.

[11] Håkansson L. Epistemic Communities and Cluster Dynamics: On the Role of Knowledge in Industrial Districts. Industry and Innovation. 2005;12(4):433-63.

[12] Giuliani E. The selective nature of knowledge networks in clusters: evidence from the wine industry. Journal of Economic Geography. 2007;7:139-68.

[13] Coe N, Bunnel T. 'Spatializing 'Knowledge Communities: Towards a Conceptualization of Transnational Innovation Networks. Global Networks. 2003;3(4):437-56.

[14] Castells M. The Rise of the Network Society. Oxford: Blackwell; 1996.

[15] Boschma R. Proximity and innovation: a critical assessment. Regional Studies. 2005;39(1):61-74.

[16] Gertler M, Wolfe D. Local social management: Community actors, institutions and multilevel governance in regional foresight exercises. Futures. 2004;36:45-65.

[17] Torre A, Rallet A. Proximity and Localization. Regional Studies. 2005 February;39(1):4759.

[18] Lazerson M, Lorenzoni G. The Firms that Feed Industrial Districts: A Return to the Italian Source. Industrial and Corporate Change. 1999;8:235-65.

[19] Sheppard E. Positionality and globalization in economic geography In: Giovanna V, editor. The Changing Economic Geography of Globalization: Reinventing Space: Taylor \& Francis 2005. p. 45-72.

[20] Wolfe D, Gertler M. Clusters from the inside and out: local dynamics and global linkages. Urban Studies. 2004;41(5/6):1071-93.

[21] Bathelt H. Cluster Relations in the Media Industry: Exploring the 'Distanced Neighbour' Paradox in Leipzig. Regional Studies. 2005;39(1):105-27.

[22] Passi A. Place and region: looking through the prim of scale. Progress in Human Geography. 2004;28(4):536-46.

[23] Murdoch J. The Spaces of Actor-Network Theory. Geoforum. 1998;29(4):357-74.

[24] Graham S, Healey P. Relational Concepts of Space and Place: Issues for Planning Theory and Practice. European Planning Studies. 1999;7(5):623-46.

[25] Baraldi E. The Places of Ikea: Using Space in Handling Resource Networks. In: Baraldi E, Hjalmar F, Houltz A, editors. Taking Place: The Spatial Contexts of Science, Technology and Business. Sagamore Beach: Science History Publications/USA; 2006. p. 297-320.

[26] Baraldi E, Hjalmar F, Houltz A. Taking Place: The Spatial Contexts of Science, Technology and Business. Sagamore Beach: Science History Publications/USA; 2006.

[27] Dicken P, Malmberg A. Firms in Territories: A Relational Perspective. Economic Geography. 2001 October;77(4):345-63.

[28] Bathelt H. Geographies of production: growth regimes in spatial perspective 3 - toward a relational view of economic action and policy. Progress in Human Geography. 2006;30(2):223-36. 
[29] Amin A. Regions Unbound: Towards a New Politics of Place. Geografiska Annaler. 2004;86(1):33-44.

[30] Bathelt H, Glückler J. Toward a relational economic geography. Journal of Economic Geography. 2003;3:117-44.

[31] Boggs J, Rantisi N. The 'relational turn' in economic geography. Journal of Economic Geography. 2003;3:109-16.

[32] Dicken P, Kelly PF, Olds K, Yeung HW-C. Chains and networks, territories and scales: towards a relational framework for analysing the global economy. Global Networks. 2001 2001;1(2):89-112.

[33] Yeung HW-c. Rethinking relational economic geography. Transactions of the Institute of British Geographers. 2005 March;30:37-51.

[34] Ettlinger N. Cultural economic geography and a relational and microspace approach to trusts, rationalities, networks, and change in collaborative workplaces. Journal of Economic Geography. 2003;3:145-71.

[35] Amin A. An Institutionalist Perspective on Regional Economic Development. International Journal of Urban and Regional Research. 1999;23:365-78.

[36] Amin A, Thrift N. Globalization, Institutions and Regional Development in Europe. Oxford: Oxford University Press; 1994.

[37] Lee R. 'Nice maps, shame about the theory'? Thinking geographically about the economic. Progress in Human Geography. 2002;26(3):333-55.

[38] Murphy J. Social space and industrial development in East Africa: deconstructing the logics of industry networks in Mwanza, Tanzania. Journal of Economic Geography. 2003;3:173-98.

[39] Maskell P, Malmberg A. Myopia, Knowledge Development and Cluster Evolution. Journal of Economic Geography. 2007;7:603-18.

[40] Amin A. Globalisation and Regional Development: A Relational Perspective. Competition \& Change. 1998;3:145-65.

[41] Howit R. Scale. In: Agnew J, Mitchell K, Toal G, editors. A companion to political geography. Oxford: Blackwell; 2003. p. 138-57.

[42] Murdoch J. Towards a geography of heterogeneous associations. Progress in Human Geography. 1997;21(3):321-37.

[43] Amin A, Cohendet P. Geographies of Knowledge Formation in Firms. Industry and Innovation. 2005 December 2005;12(4):465-86.

[44] Malecki E. Knowledge and regional competitiveness. Erdkunde. 2000;54:334-51.

[45] Gibson-Graham J. Beyond global vs. local: economic politics outside the binary frame. In: Herod A, Wright M, editors. Geographies of Power: Placing Scale. Oxford: Blackwell; 2002.

[46] Taylor M, Asheim B. The concept of the firm in economic geography. Economic Geography. 2001;77(4):315-28.

[47] Yeung HW-C. The Firm as Social Networks: An Organisational Perspective. Growth \& Change. 2005 Summer;36(3):307-28. 
[48] Schoenberger E. The Firm in the Region and the Region in the Firm In: Barnes T, Gertler $\mathrm{M}$, editors. The new industrial geography: Regions, regulation and institutions. London: Routledge; 1999. p. 205-24.

[49] Glückler J. Economic geography and the evolution of networks. Journal of Economic Geography. 2007;7:619-34.

[50] Smedlund A. The roles of intermediaries in a regional knowledge system. Journal of Intellectual Capital. 2006;7(2):204-20.

[51] Bathelt H, Malmberg A, Maskell P. Clusters and knowledge: local buzz, global pipelines and the process of knowledge creation. Progress in Human Geography. 2004 February;28(1):31-56.

[52] Owen-Smith J, Powell W, editors. Knowledge networks in the Boston Biotechnology community. Science as an Institution and the Institutions of Science; 2002; Siena.

[53] Camagni R. Local 'milieu', uncertainty and innovation networks: towards a new dynamic theory of economic space. In: Camagni R, editor. Innovation Networks: Spatial Perspectives. London: Belhaven; 1991. p. 121-44.

[54] Coe N, Hess M, Yeung HW-c, Dicken P, Henderson J. 'Globalizing' regional development: a global production networks perspective. Transactions of the Institute of British Geographers. 2004;29:468-84.

[55] Cohen W, Levinthal D. Innovation and Learning: the Two Faces of R\&D. The Economic Journal. 1989;99:569-96.

[56] Cohen W, Levinthal D. Absortive capacity: A new perspective on learning and innovation. Administrative Science Quarterly. 1990;35:128-52.

[57] Muscio A. The Impact of Absorptive Capacity on SMEs' Collaboration. Economics of Innovation and New Technology. 2007;16(8):653-68.

[58] Vinding A. Human Resources: Absorptive Capacity and Innovative Performance. In: Christensen J, Lundvall B, editors. Product Innovation, Interactive Learning and Economic Performance. Oxford: Elsevier; 2004.

[59] Huselid M. The Impact of Human Resource Management on Turnover, Productivity and Corporate Financial Performance. Academy of Management Journal. 1995;38:63560 .

[60] Lee C-K, Saxenian A. Coevolution and coordination: a systemic analysis of the Taiwanese information technology industry. Journal of Economic Geography. 2008;8:157-80.

[61] Lane C. National Capitalisms, Global Production Networks: An Analysis of their interaction in two global industries. Socio-Economic Review 2008;6(2):227-60.

[62] Grabher G. Trading routes, bypasses, and risky intersections: mapping the travels of 'networks' between economic sociology and economic geography. Progress in Human Geography. 2006;30(2):163-89.

[63] Staber U. The Structure of Networks in Industrial Districts. International Journal of Urban and Regional Research. 2001;25:537-52.

[64] Håkansson H, Waluszewski A. Managing Technological Development. IKEA, the environment and technology. London: Routledge; 2002. 
[65] Brito C. Estrutura e Dinâmica do Sector do Vinho do Porto. Porto: Instituto do Vinho do Porto; 1997.

[66] Henneberg S, Mouzas S. Network Pictures: Concepts and Representations. European Journal of Marketing. 2006;40(3/4):408-29.

[67] Astley W. Toward an Appreciation of Collective Strategy. Academy of Management Review. 1984;9(3):526-35.

[68] Håkansson H, Snehota I. No Business is an Island Scandinavian Journal of Management. 1989;5(3):187-200.

[69] Thorelli H. Networks: Between Markets and Hierarchies. Strategic Management Journal. 1986;7(1):37-51.

[70] Easton G, Håkansson H. Markets as Networks: Editorial Introduction. International Journal of Research in Marketing. 1996;13:407-13.

[71] Anderson J, Håkansson H, Johanson J. Dyadic Business Relationships Within a Business Network Context. Journal of Marketing. 1994;58(4):1-15.

[72] Lundberg H. Geographical Proximity Effects and Regional Strategic Networks. Doctoral Thesis, Department of Business Studies, Uppsala University. 2008.

[73] Johanson J, Mattsson L. Network Positions and Strategic Actions - An Analytical Framework. In: Axelsson B, Easton G, editors. Industrial Networks: A New View of Reality. London: Routledge; 1992. p. 205-17.

[74] Mattsson L-G. Reorganisation of Distribution in Globalisation of Markets: The Dynamic Context of Supply Chain Management. Supply Chain Management: An International Journal 2003;8(5):416-26.

[75] Brito C. Towards an institutional theory of the dynamics of industrial networks. Journal of Business \& Industrial Marketing. 2001;16(3):150-66.

[76] Snehota I. Perspectives and theories of market. In: Håkansson H, Harrison D, Waluszewski A, editors. Rethinking Marketing: Developing a New Understanding of Markets. Chichester: Wiley 2004. p. 15-32.

[77] Duysters G, Man A-P, Wildeman L. A Network Approach to Alliance Management. European Management Journal. 1999;17(2):182-7.

[78] Turnbull P, Ford D, Cunningham M. Interaction, relationships and networks in business markets: an evolving perspective. Journal of Business \& Industrial Marketing. 1996;11(3/4):44-62.

[79] Wilkinson I, Young L. On Cooperating: Firms, Relations and Networks. Journal of Business Research. 2002;55(2):123-32.

[80] Gulati R, Nohria N, Zaheer A. Strategic Networks. Strategic Management Journal. 2000;21:203-15.

[81] Henders B. Positions in Industrial Networks, Marketing Newsprint in the UK PhD thesis, Uppsala University, Department of Business Studies, Uppsala, Sweden; 1992

[82] Low B. Managing Business Relationships and Positions in Industrial Networks. Industrial Marketing Management. 1997;26(2):189-202.

[83] Ford D, Håkansson H. IMP - some things achieved: much more to do. European Journal of Marketing. 2006;40(3/4):248-58. 
[84] Baraldi E, Brennan R, Harrison D, Tunisini A, Zolkiewski J. Strategic thinking and the IMP approach: A comparative analysis. Industrial Marketing Management. 2007;36(7):879-94.

[85] Araújo L, Dubois A, Gadde L-E. Managing Interfaces With Suppliers. Industrial Marketing Management. 1999;28(5):497-506.

[86] Gadde L-E, Huemer L, Håkansson H. Strategizing in Industrial Networks. Industrial Marketing Management. 2003;32(5):357-64.

[87] Araújo L, Dubois A, Gadde L-E. The Multiple Boundaries of the Firm. Journal of Management Studies. 2003;40(5):1255-77.

[88] Snehota I. Notes on a Theory of Business Enterprise: PhD Thesis, Uppsala University; 1990.

[89] Jüttner U, Schlange L. A network approach to strategy. International Journal of Research in Marketing. 1996;13:479-94.

[90] Holmen E, Pedersen A-C. Strategizing Through Analyzing and Influencing the Network Horizon. Industrial Marketing Management. 2003;32:409-18.

[91] Ford D, Håkansson H. The Idea of Business Interaction. IMP Journal. 2006;1(1):4-20.

[92] Baraldi E, Stromsten T. Combining Scientific Knowledge and Venture Capital Across Places and Networks of Resources. In: Houltz A, Hjalmar F, Baraldi E, editors. Taking Place: The Spatial Contexts of Science, Technology and Business. Sagamore Beach: Science History Publications/USA; 2006. p. 247-73.

[93] Cova B, Mazet F, Salle R. Milieu as a Pertinent Unit of Analysis in Project Marketing. International Business Review. 1996;5(6):647-64.

[94] Håkansson H, Tunisini A, Waluszewski A. Place as a Resource in Business Networks. In: Houltz A, Hjalmar F, Baraldi E, editors. Taking Place: The Spatial Contexts of Science, Technology and Business. Sagamore Beach: Science History Publications/USA; 2006. p. 223-46.

[95] Johnston B, Araújo L, editors. The Effects of Spatial Proximity on Inter-Organisational Relationships. 18th IMP Annual Conference; 2002.

[96] Mota J, Castro L. Industrial agglomerations as localised networks: the case of the Portuguese injection mould industry. Environment and Planning A. 2004;36:263-78.

[97] Ford D. The development of buyer-seller relationships in industrial markets. London: Thomson Learning; 2002.

[98] Huemer L, Becerra M, Lunnan R. Organizational Identity and Network Identification: Relating Within and Beyond Imaginary Boundaries. Scandinavian Journal of Management. 2004;20(1/2):53-73.

[99] Håkansson H, Johanson J. A Model of Industrial Networks. In: Axelsson B, Easton G, editors. Industrial Networks: A New View of Reality. London: Routledge; 1992. p. 2834.

[100] Håkansson H, Snehota I. Developing Relationships in Business Networks. London: Routledge; 1995.

[101] Mattsson L-G. Industrial Marketing the Network Perspective. In: Backhaus K, Voeth M, editors. Handbuch Industriegüter Marketing: Gabler Verlag; 2004. 
[102] Hadjikhani A, Thilenius P. The impact of horizontal and vertical connections on relationships' commitment and trust. Journal of Business \& Industrial Marketing. 2005;20(3):136-47.

[103] Waluszewski A, Ford D, Håkansson H, Snehota I, Gadde L-E, editors. Analysing Business Interaction. 24th IMP Conference; 2008; Uppsala, Sweden. 